\title{
First Molecular Characterization of Hysterothylacium Fabri Larvae (Nematoda: Raphidascarididae) in the Mediterranean Sea Based on the Small Subunit Ribosomal RNA Gene Sequence
}

\author{
Emrah ŞİMŞEK¹, Neslihan SÜRSAL², Gupse Kübra KARADEMİR³, Gökmen Zafer PEKMEZCí4* \\ ${ }^{1}$ Erciyes University, Faculty of Veterinary Medicine, Department of Aquatic Animal Diseases, TR-38039, Kayseri, Turkey \\ 2 Aksaray University, Faculty of Veterinary Medicine, Department of Parasitology, Aksaray, Turkey \\ ${ }^{3}$ Erciyes University, Faculty of Veterinary Medicine, Department of Parasitology, TR-38039, Kayseri, Turkey \\ ${ }^{4}$ Ondokuz Mayis University, Faculty of Veterinary Medicine, Department of Aquatic Animal Diseases, TR-55200, Samsun, Turkey
}

\begin{abstract}
Hysterothylacium fabri is commonly reported in various Mediterranean fish. However, there is no data on the mitochondrial ribosomal RNA ( $r n S$ ) gene sequence of $H$. fabri larvae in the Mediterranean Sea waters. Therefore, we aimed to reveal molecular characterization of $H$. fabri based on the rmS gene sequence in the current study. Firstly, the fourth stage of $H$. fabri larvae were identified at parasitological examination from Mullus barbatus in the Mediterranean Sea. Morphologically identified H. fabri larvae herein were also supported by the sequencing of the nuclear ribosomal ITS gene regions. In the next step, the $r m S$ gene of these larvae was molecularly analysed. Our H. fabri isolate (MK886659) showed 96.42\% identity with $H$. fabri reported from China (MF140349) based on the rrnS gene. The nucleotide difference based on the rrnS gene between Chinese isolate (MF140349) and our H. fabri isolate (MK886659) was determined as 3.2\%. Consequently, for the first time, the mitochondrial rrnS gene sequencing of $H$. fabri from the Mediterranean waters were performed in the current study.
\end{abstract}

Keywords: Hysterotbylacium fabri, Mediterranean Sea, Mitochondrial rrnS gene, Molecular characterization

\section{Akdeniz'deki Hysterothylacium Fabri (Nematoda: Raphidascarididae) Larvasının İlk Kez Küçük Alt Ünite Ribozomal RNA Gen Bölgesinin Sekansına Göre Moleküler Karakterizasyonu}

\section{ÖZ}

Hysterotbylacium fabri sıklıkla farklı türdeki Akdeniz balıklarında bildirilmektedir. Ancak, Akdeniz sularındaki H. fabri larvasının mitokondriyal ribozomal RNA (rrnS) gen bölgesinin sekansı üzerine herhangi bir veri bulunmamaktadır. $\mathrm{Bu}$ yüzden, bu çalışmada, $H$. fabri'nin $r r n S$ gen bölgesinin sekansına göre moleküler karakterizasyonunu ortaya koymayı amaçladık. İlk olarak, Akdeniz'deki Mullus barbatus'tan dördüncü dönem $H$. fabri larvaları parazitolojik muayenede teşhis edildi. Burada morfolojik olarak teşhis edilen H. fabri, nükleer ribozomal ITS gen bölgesinin DNA dizi analizi ile de desteklendi. Bir sonraki aşamada ise bu larvaların $r r n S$ geni moleküler olarak analiz edildi. RrnS gen bölgesine göre, H. fabri izolatımız (MK886659) Çin'den rapor edilen H. fabri (MF140349) ile \%96,42 oranında benzerlik gösterdi. Çin (MF140349) izolatı ile H. fabri (MK886659) izolatımız arasındaki nükleotid farklılığı ise rrnS genine göre \%3,2 olarak belirlendi. Sonuç olarak bu araştırma ile ilk kez Akdeniz sularından $H$. fabrinin mitokondriyal $r m S$ sekanslaması gerçekleştirildi.

Anahtar sözcükler: Akdeniz, Hysterothylacium fabri, Mitokondriyal rmS gen, Moleküler karakterizasyon

To cite this article: Simsek E. Sürsal N. Karademir G.K. Pekmezci G.Z. First Molecular Characterization of the Small Subunit Ribosomal RNA Gene of

Hysterothylacium Fabri Larvae (Nematoda: Raphidascarididae) from Mediterranean Sea. Kocatepe Vet J. (2021):14(1):71-76

Submission: 26.11.2020 Accepted: 10.02.2021 Published Online: 20.02 .2021

ORCID ID; EȘ: 0000-0002-0492-9840, NS: 0000-0002-4144-9520, GKK: 0000-0002-3594-1770, GZP: 0000-0002-7791-1959

*Corresponding author e-mail: zpekmezci@omu.edu.tr 


\section{INTRODUCTION}

Hysterotbylacium species are marine ascaridoids and over 70 recognizable species have been described in the worldwide (Moravec and Justine 2015). Hysterotbylacium species were reported as larvae and adults in various marine teleost from the Mediterranean Sea (Barcala et al. 2018; Costa et al. 2018; Gazzonis et al. 2017; Keskin et al. 2015; Pekmezci et al. 2014; Petter and Maillard 1988; Roca-Gerones et al. 2018; Simsek et al. 2018; Szostakowska et al. 2001; Tedesco et al. 2018). Until now, five Hysterothylacium larval morphotypes (III, IV, V, VIII, IX) and $H$. reliquens, $H$. fabri, $H$. aduncum, and $H$. girgenti have been genetically identified using ribosomal and mitochondrial DNA markers in the Mediterranean waters (Barcala et al. 2018; Costa et al. 2018; Keskin et al. 2015; Pekmezci et al. 2014; RocaGerones et al. 2018; Simsek et al. 2018; Tedesco et al. 2018; Khammassi et al. 2020). There has been limited knowledge on the $H$. reliquens, $H$. fabri, and $H$. aduncum in marine teleost from Turkish Mediterranean waters (Keskin et al. 2015; Pekmezci et al. 2014; Simsek et al. 2018). Although there are molecular studies for the certain identification of marine ascaridoid species, the taxonomy of the genus Hysterothylacium in Mediterranean waters remains incomplete and unresolved (Costa et al. 2018). Moreover, there is no study on the rrnS gene sequence of molecular characterisation of $H$. fabri larvae in Mediterranean waters. Therefore, for the first time, we performed the molecular characterization of $r m S$ mitochondrial gene of $\mathrm{H}$. fabri from the Mediterranean waters.

\section{MATERIALS AND METHODS}

\section{Fish Sampling, Parasite Collection, and Morphological Examination}

For this study, ethics committee approval was not needed because no handling of live marine teleost specimens was involved. A total of forty-five fresh and dead Mullus barbatus (L.) caught from the Turkish Mediterranean coast were purchased from local fishermen between March 2018 to May 2018 and examined under a stereomicroscope for the presence of Hysterothylacium spp. larvae in the digestive tract and visceral cavity. All nematodes were mechanically removed, washed in saline, and stored in ethanol solution. A middle portion of nematodes was used for genetic identification and other portions were individually cleared with lactophenol for using morphological identification. The nematodes were identified using the location of the excretory pore, the digestive systems, and the posterior ends (Petter and Maillard 1988; Tedesco et al. 2018). A subsample of five specimens of the fourth stage of $H$. fabri larvae was randomly selected and subjected to molecular analysis using a small middle portion of the nematodes.
DNA Extractions, PCR Amplifications, DNA Sequencing, and Phylogenetic Analysis

Genomic DNA was extracted from individual nematodes using the DNA extraction kit (GeneJET Genomic DNA Purification Kit, Thermo Scientific, Waltham, MA, USA) following to the manufacturer's instructions. The PCR amplification targeting the nuclear ribosomal ITS gene and the mitochondrial ribosomal RNA ( $r m S$ ) gene were performed with the primers NC5/NC2 and MH3/MH4.5 primer pairs, respectively (D'Amelio et al. 2007; Zhu et al. 1998). For ITS gene, PCR mixture was prepared according to previously described by Pekmezci et al. (2014). PCR was carried out in a final volume of $50 \mu \mathrm{l}$, containing 10-50 ng of extracted DNA, $1 \times$ Taq Buffer with KCI (Thermo Scientific), $3 \mathrm{mM}$ of $\mathrm{MgCl} 2$ (Thermo Scientific), $0.3 \mathrm{mM}$ dNTPs (Thermo Scientific), 2 pmol of each primer, $2.5 \mathrm{U}$ of Taq DNA Polymerase (Thermo Scientific), and DEPC-treated water. The PCR conditions were as follows: $15 \mathrm{~min}$ at $95{ }^{\circ} \mathrm{C}$, then 30 cycles of $1 \mathrm{~min}$ at $94{ }^{\circ} \mathrm{C}, 1 \mathrm{~min}$ at $55^{\circ} \mathrm{C}$ and $1 \mathrm{~min}$ at $72{ }^{\circ} \mathrm{C}$ followed by a final elongation of $5 \mathrm{~min}$ at 72 ${ }^{\circ} \mathrm{C}$. For $r r n S$ gene, PCR mixture was prepared according to previously described by $\mathrm{D}^{\prime}$ Amelio et al. (2007) and PCR reaction (50 $\mu$ l) was contained 20-40 ng of extracted DNA, $10 \mathrm{mM}$ Tris-HCl (pH 8. 3), 50 $\mathrm{mM} \mathrm{KCl}$ (Thermo Scientific), $3 \mathrm{mM} \mathrm{MgCl} 2$ (Thermo Scientific), $1 \mathrm{mM}$ of dNTPs (Thermo Scientific), 50 pM of each primer, $0.5 \mathrm{ml}$ of Taq DNA Polymerase (Thermo Scientific). The PCR conditions were as follows: 10 min at $95^{\circ} \mathrm{C}$, then 35 cycles of $30 \mathrm{sec}$ at 95 ${ }^{\circ} \mathrm{C}, 30 \mathrm{sec}$ at $55^{\circ} \mathrm{C}$ and $30 \mathrm{sec}$ at $72{ }^{\circ} \mathrm{C}$ followed by a final elongation of $7 \mathrm{~min}$ at $72 \mathrm{C}$.

Positive PCR products were purified and sent to Macrogen company for DNA sequencing. The raw sequence data were analysed using Geneious R11 (Kearse et al. 2012). The contigs were compared with all Hysterothylacium species sequences using the BLASTn algorithm via GenBank (Altschul et al. 1997). Pairwise distances using a Kimura 2-parameter and best of the nucleotide substitution model were calculated in MEGA 7.0 (Kumar et al. 2016). The TN93+G+I model for rrnS gene sequences was selected using Akaine Information Criterion. The $r m S$ datasets were used for maximum likelihood phylogenetic tree by bootstrap of 1000 replicates (Felsenstein 1985). The newly generated $r m S$ sequence was deposited in the GenBank under the accession number: MK886659.

\section{RESULTS}

The prevalence of the Hysterothylacium larvae in the Mediterranean Sea was detected as 10\% (4/40) in $M$. barbatus. The morphology of selected specimens agrees well with the description of the fourth stage of H. fabri larvae (Figure 1). 


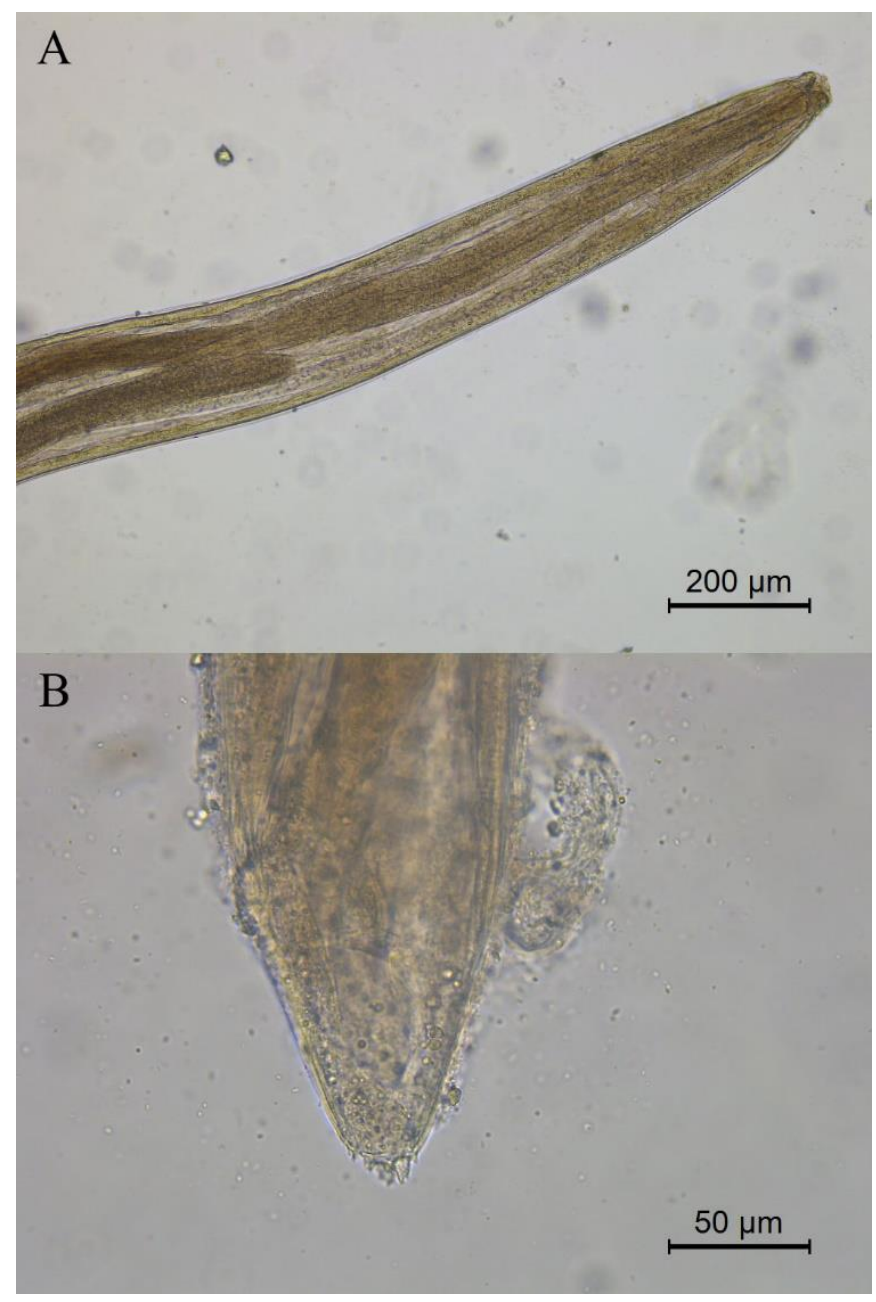

Figure 1: Microphotographs showing main morphological features of $H$. fabri larvae from the Mediterranean Sea: (A) anterior end (scale: $200 \mu \mathrm{m}$ ), (B) posterior end (scale: $50 \mu \mathrm{m}$ ).

The final length of the contig nucleotide sequences of the $r m S$ and ITS gene regions were $490 \mathrm{bp}$ and $955 \mathrm{bp}$, respectively. No intraspecific nucleotide differences were detected in the sequence analyses of partial $\mathrm{rm} S$ and ITS region. Our H. fabri isolates displayed $98.90-$ $100 \%$ identity to that of the ITS sequences of $H$. fabri (accession from JX974558, MH211474-94, MF539787-89, JQ520158, KU948632-37, KC852206) recorded previously from the Mediterranean Sea, South Korean waters, and Chinese waters (Chen et al. 2018; Pekmezci et al. 2014; Tedesco et al. 2018; Zhang et al. 2018). Moreover, our H. fabri isolates
(MK886659) showed 96.42\% identity with H. fabri from China (MF140349) based on rmS gene. The nucleotide difference based on $r r n S$ gene between the Chinese isolate (MF140349) and our H. fabri isolate (MK886659) was determined as 3.2\%. In phylogenetic analysis, our Mediterranean waters isolate of $H$. fabri (MK886659) and China isolate of H. fabri (MF140349) were also clustered together in the ML tree (Figure 2) according to $r m S$ dataset. 


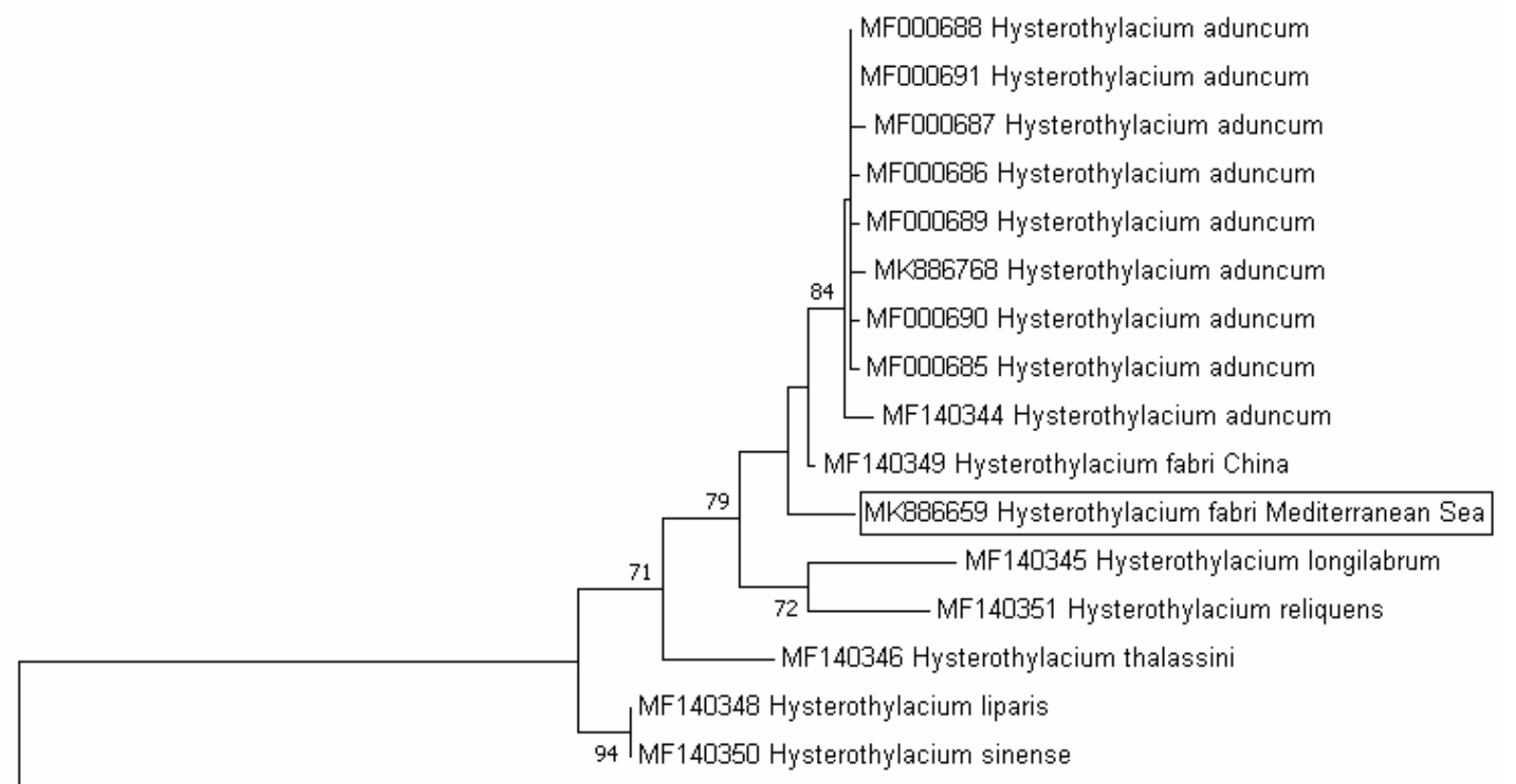

MG515234 Contracaecum overstreeti

\subsection{5}

Figure 2: Phylogenetic relationships between our H. fabri (MK886659) isolate and other Hysterothylacium species as inferred by maximum likelihood obtained from $r m S$ gene. The scale bar indicates the distance in substitutions per nucleotide. Bootstrap values were calculated over 1,000 replicates and percentages $\geq 70 \%$ are shown at the internal nodes. Contracaecum overstreeti was used as out group.

\section{DISCUSSION}

The paper on morphological identification of Hysterotbylacium larvae published by Petter and Maillard (Petter and Maillard 1988) described the third (L3) and fourth (L4) stage of $H$. aduncum larvae, L3 and L4 of $H$. fabri larvae, L4 of $H$. arnoglossi larvae and L3 and L4 of Hysterothylacium sp. I and II larvae from the Mediterranean Sea. Recently, L3 and L4 stage and adult of $H$. fabri were also morphologically identified from the Mediterranean Sea (Tedesco et al. 2018). In the present study, our specimens were morphologically identified as L4 of $H$. fabri according to the identification key (Petter and Maillard 1988; Tedesco et al. 2018). Moreover, the morphological identification of $H$. fabri reported herein was also supported by molecular analyses. Our ITS regions sequence of L4 of $\mathrm{H}$. fabri isolate displayed 98.90$100 \%$ identity (97\% query cover) with the ITS sequences of $H$. fabri (JX974558, MH211474-94, MF539787-89, JQ520158, KU948632-37, KC852206) from the Mediterranean Sea, South Korean waters, and Chinese waters (Chen et al. 2018; Pekmezci et al. 2014; Tedesco et al. 2018; Zhang et al. 2018). Therefore, previously morphologically classified L4 of $H$. fabri larvae were also genetically confirmed as $H$. fabri based on the ITS regions. Herein, for the first time, we also determined the $r r n S$ mitochondrial sequences of $H$. fabri from the Mediterranean waters. However, there was one sequence for the rmS gene of $H$. fabri (MF140349) recorded previously from China deposited in GenBank for comparison (Li et al. 2018). Interestingly, the $\% 3.2$ genetic distance was observed among $\mathrm{rmS}$ sequences of $\mathrm{H}$. fabri comparable to those reported ( $\mathrm{Li}$ et al. 2018) and the present study. Nucleotide identity of the ribosomal and mitochondrial DNA higher than $96 \%$ for Anisakidae and Raphidascarididae are considered to be the same species (da Fonseca et al. 2016). Moreover, other known $H$. aduncum species exhibited low level of intraspecific nucleotide differences ( $\mathrm{p}$ distance $=0.004$ to 0.009) between the Black Sea (MK886768) and the Mediterranean Sea isolates (MF000685-MF000691) for $r r n S$ gene, whereas; high intraspecific genetic diversity ( $\mathrm{p}$ distance $=0.021$ ) in the same species was also detected between Black Sea (MK886768) and China (MF140344) isolates (Pekmezci 2019). Therefore, the rrnS mitochondrial nucleotide differences between the China and our Mediterranean isolates of $H$. fabri should be considered as intraspecific nucleotide variation. Additionally, there may be intraspecific nucleotide differences between the remote communities of the same Hysterotbylacium species from different geographic area. Moreover, several authors accept $H$. fabri collected from marine fish in the Mediterranean and Chinese waters to be a complex comprising at least two or three sibling species (Guo et al. 2014; Martin-Sanchez et al. 2003). 
In the present study, high nucleotide variability $(3.2 \%$ nucleotide difference) was detected in the rrnS sequences of Mediterranean (MK886659) and the China (MF140349) isolates of H. fabri. Thus, we also considered $H$. fabri as sibling species according to $\mathrm{rm} S$ gene.

In conclusion, for the first time, we determined the mitochondrial rrnS data of $H$. fabri from the Mediterranean Sea in the present study. These molecular results provided species-specific genetic identification of $H$. fabri from the Mediterranean waters based on $r m S$ gene. More studies are needed to investigate the nucleotide variability by using various gene markers both larvae and adults of Hysterothylacium species from the Mediterranean waters.

Financial Support: This research received no grant from any funding agency/sector.

Ethics Committee Information: This study is not subject to the permission of HADYEK in accordance with Article $8(\mathrm{k})$ of the "Regulation on Working Procedures and Principles of Animal Experiments Ethics Committees".

Conflict of Interest: The authors declared that there is no conflict of interest.

\section{REFERENCES}

Altschul SF, Madden TL, Schaffer AA, Zhang J, Zhang Z, Miller W, Lipman DJ. Gapped BLAST and PSIBLAST: a new generation of protein database search programs. Nucleic Acids Res. 1997; 25:3389-402.

Barcala E, Ramilo A, Ortega N, Pico G, Abollo E, Pascual S, Munoz P. Occurrence of Anisakis and Hysterotbylacium larvae in commercial fish from Balearic Sea (Western Mediterranean Sea). Parasitol Res. 2018; 117:4003-4012.

Chen HX, Zhang LP, Gibson DI, Lu L, Xu Z, Li HT, Ju HD, Li L. Detection of ascaridoid nematode parasites in the important marine food-fish Conger myriaster (Brevoort) (Anguilliformes: Congridae) from the Zhoushan Fishery, China. Parasit Vectors. 2018; 11:274.

Costa A, Graci S, Cammilleri G, Buscemi MD, Collura R, Vella A, Ferrantelli V. Molecular identification of Hysterothylacium spp. in fishes from the Southern Mediterranean Sea (Southern Italy). J Parasitol. 2018; 104:398-406.

D'Amelio S, Barros N, Ingrosso S, Fauquier D, Russo R, Paggi L. Genetic characterization of members of the genus Contracaecum (Nematoda: Anisakidae) from fisheating birds from west-central Florida, USA, with evidence of new species. Parasitology. 2007; 134:1041.

da Fonseca MCG, Knoff M, Felizardo NN, Di Azevedo MIN, Torres EJL, Gomes DC, Iñiguez AM, de São Clemente SC. Integrative taxonomy of Anisakidae and Raphidascarididae (Nematoda) in Paralichthys patagonicus and Xystreurys rasile (Pisces: Teleostei) from Brazil. Int J Food Microbiol. 2016; 235:113-124.

Felsenstein J. Confidence limits on phylogenies: an approach using the bootstrap. Evolution. 1985; 39:783-791.

Gazzonis AL, Cavallero S, Zanzani SA, Olivieri E, Malandra R, Ranghieri V, D'Amelio S, Manfredi MT. Anisakis sp. and Hysterothylacium sp. larvae in anchovies (Engraulis encrasicolus) and chub mackerel (Scomber colias) in the Mediterranean Sea: Molecular identification and risk factors. Food Control. 2017; 80:366-373.

Guo YN, Xu Z, Zhang LP, Hu YH, Li L. Occurrence of Hysterothylacium and Anisakis nematodes (Ascaridida: Ascaridoidea) in the tanaka's snailfish Liparis tanakae (Gilbert \& Burke) (Scorpaeniformes: Liparidae). Parasitol Res. 2014; 113:1289-300.

Kearse M, Moir R, Wilson A, Stones-Havas S, Cheung M, Sturrock S, Buxton S, Cooper A, Markowitz S, Duran C, Thierer T, Ashton B, Meintjes P, Drummond A. Geneious Basic: an integrated and extendable desktop software platform for the organization and analysis of sequence data. Bioinformatics. 2012; 28:1647-9.

Keskin E, Koyuncu CE, Genc E. Molecular identification of Hysterothylacium aduncum specimens isolated from commercially important fish species of Eastern Mediterranean Sea using mtDNA cox1 and ITS rDNA gene sequences. Parasitol Int. 2015; 64:222-228.

Kumar S, Stecher G, Tamura K. MEGA7: Molecular Evolutionary Genetics Analysis Version 7.0 for Bigger Datasets. Mol Biol Evol. 2016; 33:1870-4.

Li L, Lü L, Nadler SA, Gibson DI, Zhang LP, Chen HX, Zhao WT, Guo YN. Molecular phylogeny and dating reveal a terrestrial origin in the Early Carboniferous for ascaridoid nematodes. Syst Biol. 2018; 67:888-900.

Martin-Sanchez J, Diaz M, Artacho ME, Valero A. Molecular arguments for considering Hysterothylacium fabri (Nematoda: Anisakidae) a complex of sibling species. Parasitol Res. 2003; 89:214-20.

Moravec F, Justine JL. Anisakid nematodes (Nematoda: Anisakidae) from the marine fishes Plectropomus laevis Lacepede (Serranidae) and Sphyraena qenie Klunzinger (Sphyraenidae) off New Caledonia, including two new species of Hysterothylacium Ward \& Magath, 1917. Syst Parasitol. 2015; 92:181-95.

Pekmezci GZ. Molecular characterization of Hysterothylacium aduncum (Nematoda: Raphidascarididae) larvae infecting Merlangius merlangus euxinus (Linnaeus, 1758) from the Turkish Black Sea coast based on mitochondrial small subunit ribosomal RNA gene analysis. Etlik Vet Mikrobiol Derg. 2019; 30:64-69.

Pekmezci GZ, Yardimci B, Onuk EE, Umur S. Molecular characterization of Hysterothylacium fabri (Nematoda: Anisakidae) from Zeus faber (Pisces: Zeidae) caught off the Mediterranean coasts of Turkey based on nuclear ribosomal and mitochondrial DNA sequences. Parasitol Int. 2014; 63:127-31.

Petter AJ, Maillard C. Larves d'ascarides parasites de poissons en Méditerranée occidentale. Bull Mus Natl Hist Nat. 1988; 10:347-369.

Roca-Gerones X, Montoliu I, Godinez-Gonzalez C, Fisa R, Shamsi S. Morphological and genetic characterization of Hysterothylacium Ward \& Magath, 1917 (Nematoda: Raphidascarididae) larvae in horse mackerel, blue whiting and anchovy from Spanish Atlantic and Mediterranean waters. J Fish Dis. 2018; 41:1463-1475.

Simsek E, Ciloglu A, Yildirim A, Pekmezci GZ. Identification and molecular characterization of Hysterothylacium (Nematoda: Raphidascarididae) larvae in bogue (Boops boops L.) from the Aegean Sea, Turkey. Kafkas Üniv Vet Fak Derg. 2018; 24.

Szostakowska B, Myjak P, Kur J, Sywula T. Molecular evaluation of Hysterothylacium auctum (Nematoda, Ascaridida, Raphidascarididae) taxonomy. Acta Parasitol. 2001; 46:194-201.

Tedesco P, Gustinelli A, Caffara M, Patarnello P, Terlizzi A, Fioravanti ML. Hysterotbylacium fabri (Nematoda: 
Raphidascarididae) in Mullus surmuletus (Perciformes: Mullidae) and Uranoscopus scaber (Perciformes:

Uranoscopidae) from the Mediterranean. J Parasitol.

2018; 104:262-274.

Zhang K, Xu Z, Chen HX, Guo N, Li L. Anisakid and raphidascaridid nematodes (Ascaridoidea) infection in the important marine food-fish Lophius litulon (Jordan)

(Lophiiformes: Lophiidae). Int J Food Microbiol. 2018; 284:105-111.

Zhu X, Gasser RB, Podolska M, Chilton NB. Characterisation of anisakid nematodes with zoonotic potential by nuclear ribosomal DNA sequences. Int J Parasitol. 1998; 28:1911-21. 